\title{
From unavoidable food waste to advanced biomaterials: microfibrilated lignocellulose production by microwave- assisted hydrothermal treatment of cassava peel and almond hull
}

\author{
Allyn P. Sulaeman · Yang Gao • Tom Dugmore • Javier Remón • \\ Avtar S. Matharu (i)
}

Received: 16 November 2020/Accepted: 4 June 2021/Published online: 28 June 2021

(C) The Author(s) 2021

\begin{abstract}
Lignocellulose based nanomaterials are emerging green biosolids commonly obtained from wood pulp. Alternative feedstocks, such as as unavoidable food waste, are interesting resources for nano/ microfibers. This research reports the production and characterization of microfibrillated lignocellulose (MFLC) from cassava peel (CP) and almond hull (AH) via acid-free microwave-assisted hydrothermal treatment (MHT) at different temperatures $\left(120-220^{\circ} \mathrm{C}\right)$. During processing, the structural changes were tracked by ATR-IR, TGA, XRD, ${ }^{13} \mathrm{C}$ CPMAS NMR, zeta potential, HPLC, elemental analysis (CHN; carbon, hydrogen and nitrogen),
\end{abstract}

Supplementary Information The online version contains supplementary material available at https://doi.org/10.1007/ s10570-021-03986-5.

A. P. Sulaeman · Y. Gao · T. Dugmore

A. S. Matharu $(\square)$

Green Chemistry Centre of Excellence, Department of

Chemistry, University of York, York YO10 5DD,

England, UK

e-mail: avtar.matharu@york.ac.uk

A. P. Sulaeman

Department of Chemistry, Faculty of Mathematics and

Natural Sciences, Universitas Padjadjaran, Jln. Raya

Bandung - Sumedang Km 21, Jatinangor 45363,

Indonesia

J. Remón

Instituto de Carboquímica, CSIC, C/Miguel Luesma

Castán 4, 50018 Zaragoza, Spain
TEM and SEM analyses. The microwave processing temperature and nature of feedstock exerted a significant influence on the yields and properties of the MFLCs produced. The MFLC yields from $\mathrm{CP}$ and $\mathrm{AH}$ shifted by $15-49 \%$ and $31-73 \%$, respectively. Increasing the MHT temperature substantially affected the crystallinity index (13-66\% for CP and 36-62\% for $\mathrm{AH})$ and thermal stability $\left(300-374{ }^{\circ} \mathrm{C}\right.$ for $\mathrm{CP}$ and 300-364 ${ }^{\circ} \mathrm{C}$ for $\mathrm{AH}$ ) of the MFLCs produced. This suggested that the MFLC from CP is more fragile and brittle than that produced from $\mathrm{AH}$. These phenomena influenced the gelation capabilities of the fibers. AH MFLC pretreated with ethanol at low temperature gave better film-forming capabilities, while untreated and heptane pretreated materials formed stable hydrogels at solid concentration $(2 \% \mathrm{w} / \mathrm{v})$. At high processing temperatures, the microfibrils were separated into elementary fibers, regardless of pretreatment or feedstock type. Given these data, this work demonstrates that the acid-free MHT processing of $\mathrm{CP}$ and $\mathrm{AH}$ is a facile method for producing MFLC with potential applications, including adsorption, packaging and the production of nanocomposites and personal care rheology modifiers. 


\section{Graphic abstract}

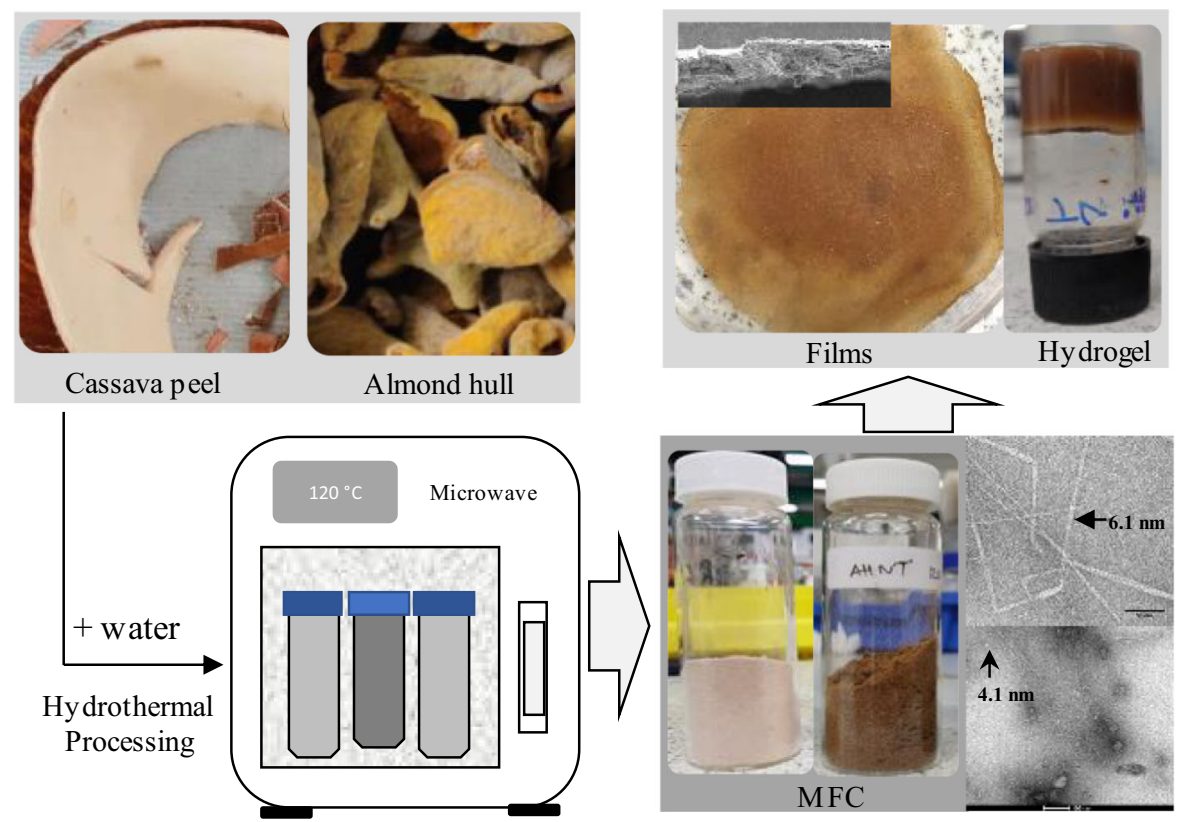

Keywords Microfibrillated lignocellulose ·

Microwave hydrothermal · Cassava peel · Almond hull

\section{Introduction}

Presently, inefficiencies in the food system from farm to fork generates approximately 1.3 billion tonnes per year of food waste (both avoidable and unavoidable) (Matharu et al. 2016a). Food waste accounts for almost \$1 trillion in economic loss, notwithstanding negative environmental and social impacts (FAO 2014). Our current food supply chain is often linear, where considerable resources are lost (Ronzon et al. 2017). As such, food waste has become a global, highly topical, and modern-day dilemma because of its adverse economic, environmental and social impacts. A change from linear- to circular-thinking is required, where the resources are retained rather than lost.

Unavoidable food supply chain wastes generated because of primary and secondary processing are recognized as a potential, abundant and natural source of biobased chemicals, materials and bioenergy. For example, in 2018, the global production of cassava
(Manihot esculenta Crantz) amounted to 277 million tonnes (fresh root equivalent), with Nigeria, Thailand and Indonesia being the top three producers (FAO 2018). The main product from the cassava industry, e.g., tapioca flour, generates cassava peel as an unavoidable food waste, which represents approximately between 15 and 20\% of the tuber (Pandey et al. 2000; Obadina et al. 2006). Whilst, global almond crops contribute to the production of 1.4 million tonnes of biomass per year which include shells, hulls, pruning wastes, leaves, skins, and inedible kernels (Holtman et al. 2015). During the processing of almonds, the kernel, shell and hull account for $15 \%$, $33 \%$ and $52 \%$, respectively, of the waste (FerrandezVillena et al. 2019). Both by-products, cassava peel and almond hull, are unavoidable and have the potential to be renewable materials for nanocellulose production.

The hierarchical defibrillation process of a bundle of cellulosic fibers using top-down destruction enables the production of micro- and nano-cellulose (Salas et al. 2014). A wide variety of methods, including chemical treatment (e.g., alkaline-acid treatment, 2,2,6,6-tetramethylpiperidine-1-oxyl radical (TEMPO) oxidation, delignification, maceration 
and fractionation), enzymatic treatment (e.g., Acetobacter xylinum, and Trichoderma reesei) and physical treatments (high-pressure homogenization, steam explosion microfluidization, grinding, cryocrushing, microwave and ultrasound) allow for nanofibrillated cellulose (NFC) or microfibrillated cellulose (MFC) isolation from the non-cellulosic materials (Abdul Khalil et al. 2014; Nasir et al. 2017; Kabakc1 and Hacıbektaşoğlu 2017; Ilyas et al. 2019; Syafri et al. 2019).

We recently reported an acid-free (and enzymaticfree) hydrothermal microwave-assisted method to produce mesoporous (nano)cellulose fibrils and crystals from biomass coined the Hy-MASS concept (De Melo et al. 2017; Matharu et al. 2018). Microwaveassisted hydrothermal treatment (MHT) offers several advantages over conventional heating, such as rapid and selective heating, internal heating from within substances, shorter reaction time, and controllable processes (Sonobe 2011).

This technology offers many improvements to the conventional procedures for nanocellulose production reported to date. Unlike traditional production of nanofibers, which typically requires use of harsh chemicals, the valorization of a feedstock via acid-free MHT (water alone) is a state-of-the-art concept for defibrillated lignocellulose production akin to microfibrils, nanofibrils, and nanocrystals. The production of microfibrillated lignocellulose materials can lead to a variety of applications, such as, chemical adsorption, manufacturing of cardboard packaging and composites, films and adhesives (Ewulonu et al. 2019; Oliaei et al. 2021). Although these nanofibers can still contain lignin and/or hemicellulose depending on hydrolysis temperature applied, they show outstanding features, such as low viscosity, good dispersability and excellent polymer matrix affinity (Jang et al. 2020; Oliaei et al. 2020).

The disintegration of cellulosic materials with a high lignin content via physical processes may slow down the fibrillation rate (Ämmälä et al. 2019). Additional pretreatment, for example, solvent extraction, could be performed to improve the hydrolysis of the fibers in microwave treatment, particularly at low or medium temperatures. The pretreatment process may impact the network of fibers and enable more access to hydroxyl hydrogen bonding (LewandowskaŁańcucka et al. 2018) as non-cellulosic compounds from the biomass have already been extracted. Solvent pretreatment, such as hot heptane extraction, removes non-polar and/or weakly polar compounds such as waxes or lipids. In contrast, hot ethanol extraction is used to dissolve polar compounds such as water, sugars, phenols, and tannins (Thakur and Arya 2014).

Thus, the aim of this work is to investigate the production of MFLC from cassava peel (CP) and almond hull $(\mathrm{AH})$ via microwave-assisted hydrothermal treatment (MHT) (quantity, quality and hydrolysate composition), and analyze how and to what extent the inclusion of a solvent extraction pretreatment with ethanol (ET) or heptane (HP) affects the process. The MFLC produced will be investigated for its potential to form hydrogels and films as they can be used in a plethora of applications, such as packaging and personal care products (Syafri et al. 2019).

\section{Experimental section}

Materials

Fresh cassava tubers were purchased from Kirkgate Market, Leeds, England. The tubers were peeled, and the white inner layer was chopped into small pieces using a knife mill, dried, ground (using a coffee grinder) into a fine powder and stored until further required. Almond hulls were harvested and collected from 'Marcona Almonds' producer farms in Zaragoza, Spain. The hulls were sprayed with ethanol (96 vol\%) to prevent mold growth during storage. The dried hulls were chopped with a knife mill, milled into a fine powder and stored until further required. The cellulose, hemicellulose and lignin content of neat CP and AH was determined by the classical titration method (Hu et al. 2014) and is given in the Supporting Information. All chemicals and solvents were purchased from Sigma Aldrich or VWR Chemical and used without further purification.

\section{Biomass pretreatment}

The appropriate solvent $[100 \mathrm{~mL}$, either ethanol (96\%) or heptane (99\%)] was added to either CP or AH powder $(20 \mathrm{~g})$ contained in a round-bottomed flask equipped with a reflux condenser. The slurry was heated under reflux for $2 \mathrm{~h}$. Thereafter, the mixture was cooled and filtered. The residues were isolated and dried for analysis and further experimentation. The 
abbreviation 'ET' refers to samples pretreated with ethanol, while 'HP' refers to samples pretreated with heptane.

\section{MFLC production}

Acid-free microwave-assisted hydrolysis was performed on $\mathrm{CP}$ and $\mathrm{AH}$ from three different samples: residue without pretreatment, ethanol extracted residue (ET) and heptane extracted residue (HP). All samples were processed in a CEM Mars 6 microwave system EasyPrep Plus ${ }^{\circledR}$ closed vessels (CEM Corp, North Carolina, United States) with a maximum energy of $600 \mathrm{~W}$ and ramp time of $20 \mathrm{~min}$. The process was conducted at different temperatures (120, 170 and $220{ }^{\circ} \mathrm{C}$ ) with 0 min hold time and a $5 \%(\mathrm{w} / \mathrm{v})$ loading (calculated as biomass/deionized-water ratio, using $2 \mathrm{~g}$ of biomass and $40 \mathrm{~mL}$ of deionized water). After the microwave reaction, the slurry was filtered, and the residue washed with water, hot ethanol $(2 \times)$ and acetone. Thereafter, the residue was dried $\left(40{ }^{\circ} \mathrm{C}\right)$ for $72 \mathrm{~h}$ or until a constant weight was achieved. The filtered solution of all samples was analyzed by HPLC. The yield (\%) of dry MFLC was calculated according to Eq. 1. All experiments were run in triplicate.

$\begin{aligned} \text { Yield }(\%)= & \frac{\text { Weight sample after hydrolysis }(\mathrm{g})}{\text { Weight sample before hydrolysis }(\mathrm{g})} \\ & \times 100\end{aligned}$

Hydrogel formation

MFLC hydrogels were produced at different concentrations $[2-7 \%(\mathrm{w} / \mathrm{v})]$, by adding deionized water to the MFLC hydrolyzed at $120^{\circ} \mathrm{C}$ in a $7 \mathrm{~mL}$ vial. The mixture was homogenized using a Ystral Homogenizer D-79282 Dottingen X10/20 E3 (Ystral, Ballrechten-Dottingen, Germany) for $5 \mathrm{~min}$ at $20,000 \mathrm{rpm}$. Next, the gel was allowed to cool to ambient temperature. The gel formation was evaluated qualitatively by means of an inversion test.

MFLC-based films

MFLC-based films were produced at a concentration of $0.2 \%(\mathrm{w} / \mathrm{v})$ in deionized water. The mixture was homogenized using a Ystral Homogenizer D-79282
Dottingen X10/20 E3 for $5 \mathrm{~min}$ at around 20,000 rpm and sonicated for $10 \mathrm{~min}$ to spread homogeneously. Afterwards, the suspensions were poured into a sintered glass filter ( $40 \mathrm{~mm}$ diameter, pore size three) covered with a polytetrafluoroethylene (PTFE) membrane filter whilst under vacuum suction. The wet MFLC films were dried at around $40{ }^{\circ} \mathrm{C}$ and stored in Petri dishes. The morphology and cross-section of the films were analyzed by SEM.

\section{Instrumental analysis}

The MFLC samples were analyzed by ATR-IR, TGA, XRD, ${ }^{13}$ C CPMAS NMR, SEM, Zeta potential, CHN, TEM, and SEM. The theoretical higher heating value (HHV) was calculated from the CHN data using a modified Channiwala's formula (Remón et al. 2018). Multiplication of $\% \mathrm{~N}$ by 6.25 (plant protein factor) affords the crude protein content (Mariotti et al. 2008). The X-ray diffraction (XRD) patterns were analyzed with an X-ray diffractometer (Bruker Powder XRD) to describe the value of the crystallinity index $(\mathrm{CI})$ based on Segal's method (Park et al. 2010). The hydrolysates produced at different temperatures were analyzed by HPLC and the method is given in the Supporting Information.

Statistical analysis of the results

The experiments were conducted in triplicate. The influence of the processing temperature, feedstock and pretreatment has been analyzed using a one-way analysis of variance (one-way ANOVA) with 95\% confidence. When the ANOVA analysis detected significant differences, a posthoc analysis utilizing the multiple ranges Fisher's least significant difference (Fisher's LSD) test was carried out to determine differences between pairs of data, i.e., either to analyze the effect of the microwave processing temperature, pretreatment method or feedstock nature. The LSD test results are presented by connection letters. Significant differences (with $95 \%$ confidence) between any pair of data can be ensured when letters are different. 


\section{Results and discussion}

\section{Compositional analysis}

Compositional analysis, including the overall cellulose, hemicellulose and lignin content, of neat CP and $\mathrm{AH}$ is listed in Table 1. The lignin content appears to be the most significant difference between the two types of biomass. The lignin content of AH (11.41\%) is almost four times higher than that of CP (3.09\%). The $\% \mathrm{C}$ and $\% \mathrm{H}$ content is comparable for both feedstocks, but there is a significant difference in their $\% \mathrm{~N}$ content; $\mathrm{CP}$ contains significantly more $\mathrm{N}$ than AH. Furthermore, CP has a slightly higher HHV than $\mathrm{AH}$.

Both types of biomass have lower cellulose and lignin content with respect to hemicellulose content. Pooja and Padmaja (2015) and Nanssou et al. (2016) reported similar physicochemical properties for cassava peel (Pooja and Padmaja 2015; Nanssou et al. 2016). The compositional analysis of almond hulls is in very good agreement with the results reported by others (González et al. 2005; Aktas et al. 2015; Remón et al. 2020).

\section{MFLC yield}

Table 2 lists the MFLC yield (\%) at different microwave processing temperature (120, 170 and $220{ }^{\circ} \mathrm{C}$ ) for cassava peel without pretreatment (CP) and with ethanol- (CPET) and heptane- (CPHP) treated residues and, similarly, for almond hull without pretreatment $(\mathrm{AH})$ and with ethanol- (AHET) and heptane-(AHHP) pretreatment. The images of the resultant MFLCs are shown in the Supporting Information, Figure S1. The MFLC yield for AH was always higher than for $\mathrm{CP}$ at all processing temperatures. This indicates more significant hydrolysis reactions for $\mathrm{CP}$ as a feedstock than for $\mathrm{AH}$, probably due to the lower lignin content in the former biomass. Irrespective of the feedstock type, the MFLC yield decreased with increasing of microwave processing temperature from 120 to 170 and to $220{ }^{\circ} \mathrm{C}$, It is well known that hemicelluloses are leached/decomposed in the region $120-150{ }^{\circ} \mathrm{C}$ under microwave conditions, whilst leaching of amorphous cellulose from with cellulose occurs above $180{ }^{\circ} \mathrm{C}$ (De Melo, 2018). These changes are manifested in the crystal structure and crystallinity index (CI), thermogravimetric analysis profiles, ${ }^{13} \mathrm{C}$ CPMAS NMR, ATR-IR and hydrolysate profile, as discussed later.

\section{ATR-IR analysis}

The ATR-IR spectra of neat $\mathrm{CP}$ and $\mathrm{AH}$, pretreatment residue and MFLCs generated at different processing temperatures are given in Supporting Information, Figure S2. Table 3 summarizes the characteristic assignment bands observed. The ATR-IR spectra of all samples exhibit a characteristic broad absorption band centered at approximately $3300 \mathrm{~cm}^{-1}$ corresponding to the $\mathrm{O}-\mathrm{H}$ stretching vibration, accounting for hydroxyl groups within cellulose combined with residual or inherent trapped water. The broadness of this absorbance band is indicative of extensive hydrogen bonding (Hospodarova et al. 2018). The $\mathrm{C}-\mathrm{O}$ polysaccharide skeletal structure is evidenced by very strong absorbance bands in the $1200-1000 \mathrm{~cm}^{-1}$ region associated with $\mathrm{C}-\mathrm{O}$ stretching mode. Specifically, the broad, prominent band at approximately $1150 \mathrm{~cm}^{-1}$ is assigned to the glycosidic linkages $(\mathrm{C}-$ $\mathrm{O}-\mathrm{C}$ ) between glucose units and the ring stretching of glucose, thus leading to absorbance bands at 1175 and $895 \mathrm{~cm}^{-1}$ (Wang and Lee 2011). C-H bonding is

Table 1 Compositional analysis

\begin{tabular}{llllllllll}
\hline Raw & $\%$ Cellulose & $\%$ Hemicellulose & $\%$ Lignin & $\% \mathrm{C}$ & $\% \mathrm{H}$ & $\% \mathrm{~N}$ & $\% \mathrm{O}^{\mathrm{a}}$ & $\mathrm{Crude}_{\mathrm{protein}}$ & $\mathrm{HHV}^{\mathrm{b}}(\mathrm{MJ} / \mathrm{kg})$ \\
\hline $\mathrm{CP}$ & $11.30 \pm 0.8$ & $22.39 \pm 1.9$ & $3.09 \pm 0.8$ & 41.63 & 6.11 & 1.57 & 50.85 & 9.81 & 16.47 \\
$\mathrm{AH}$ & $13.38 \pm 0.8$ & $24.06 \pm 3.7$ & $11.41 \pm 2.0$ & 41.26 & 5.71 & 0.86 & 52.16 & 5.38 & 15.72 \\
\hline
\end{tabular}

The remainder may comprise, for example, lipids, starch, sugars, pectins, terpenoids, polyphenolic compounds), moisture and ash (see Fig. S4 A and D)

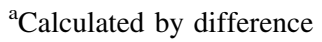

${ }^{\mathrm{b}}$ Calculated using a modified form of Channiwala's formula (Remón et al. 2018) 
Table 2 Yields (\%) of CP and AH MFLC. Results are presented as mean \pm standard deviation $(\mathrm{n}=3$ samples)

\begin{tabular}{llll}
\hline MFLC & \multicolumn{2}{l}{ Yield (\%) } & 220 \\
\cline { 2 - 4 } & 120 & 170 & $15.04 \pm 3.94(\mathrm{i})$ \\
\hline CP & $46.64 \pm 6.22(\mathrm{c}, \mathrm{d}, \mathrm{e})$ & $31.42 \pm 3.53(\mathrm{f})$ & $22.21 \pm 3.83(\mathrm{~g}, \mathrm{~h})$ \\
CPET & $43.93 \pm 4.37(\mathrm{~d}, \mathrm{e})$ & $28.34 \pm 2.40(\mathrm{f}, \mathrm{g})$ & $19.13 \pm 3.98(\mathrm{~h}, \mathrm{i})$ \\
CPHP & $47.54 \pm 2.60(\mathrm{c}, \mathrm{d}, \mathrm{e})$ & $21.14 \pm 3.46(\mathrm{~h}, \mathrm{i})$ & $30.93 \pm 2.13(\mathrm{f})$ \\
AH & $73.27 \pm 4.97(\mathrm{a})$ & $50.90 \pm 3.84(\mathrm{c})$ & $33.43 \pm 3.64(\mathrm{f})$ \\
AHET & $66.31 \pm 5.24(\mathrm{~b})$ & $45.14 \pm 2.93(\mathrm{c}, \mathrm{d}, \mathrm{e})$ & $33.59 \pm 3.90(\mathrm{f})$ \\
AHHP & $50.22 \pm 4.42(\mathrm{c}, \mathrm{d})$ & $42.90 \pm 2.72(\mathrm{e})$ & \\
\hline
\end{tabular}

Letters show statistically significant groups with $95 \%$ confidence. Values not sharing the same letter in each row and/or column are statistically different

Table 3 Common ATR-IR bands of $\mathrm{CP}$ and AH MFLC (Coates 2006; Wang and Lee 2011)

\begin{tabular}{ll}
\hline Infrared band $\left(\mathrm{cm}^{-1}\right)$ & Functional group assignment \\
\hline $3345-3300$ & O-H stretching \\
$2980-2850$ & C-H stretching \\
$1735-1695$ & C=O stretching \\
$1630-1600$ & O-H of water adsorbed \\
$1530-1500$ & $\mathrm{C}=\mathrm{C}$ stretching \\
$1450-1425$ & $\mathrm{CH}$ deformation \\
$1380-1310$ & $\mathrm{C}-\mathrm{H}$ deformation \\
$1250-1235$ & $\mathrm{O}-\mathrm{H}$ deformation \\
$1175-1100$ & $\mathrm{C}-\mathrm{O}-\mathrm{C}$ stretching \\
$1060-1000$ & $\mathrm{C}-\mathrm{O}$ stretching \\
$910-895$ & $\mathrm{C}-\mathrm{H}$ ring stretching \\
$895-885$ & $\mathrm{C}-\mathrm{H}$ out of plane bending \\
$670-650$ & $\mathrm{C}-\mathrm{OH}$ out of plane bending \\
\hline
\end{tabular}

evidenced by $\mathrm{C}-\mathrm{H}$ stretching vibrations at approx. $2900 \mathrm{~cm}^{-1}$ (Coates 2006; Paschoal et al. 2015). Often, trapped water is detected by the $\mathrm{O}-\mathrm{H}$ deformation mode, which is observed at approximately $1600 \mathrm{~cm}^{-1}$ (Kumar et al. 2014).

The effect of microwave processing temperature on $\mathrm{CP}$, either neat untreated $(\mathrm{CP})$ or pretreated (CPET, $\mathrm{CPHP}$ ) with respect to changes in functional groups, reveals the disappearance of the weak carbonyl absorption band centered at approximately $1730 \mathrm{~cm}^{-1}$. This is coupled with an increase and sharpening of the $\mathrm{C}-\mathrm{O}$ and $\mathrm{C}-\mathrm{O}-\mathrm{C}$ absorption bands in the region $1200-1000 \mathrm{~cm}^{-1}$ as the temperature increases from 120 to $170{ }^{\circ} \mathrm{C}$. These changes are attributed to the leaching of hemicellulosic and/or pectinaceous substances from both biomass types. The carbonyl absorption reappears $\left(\sim 1700 \mathrm{~cm}^{-1}\right)$ in MFLC processed at $220{ }^{\circ} \mathrm{C}(\mathrm{CP} 220, \mathrm{CPET} 220$, and CPHP220), which may be attributed to the leaching of amorphous cellulose coupled with cellulose decomposition to afford pseudo-lignins that migrate to the surface of the material. Pseudolignin is derived via polymerization reactions from furfural and 5-hydroxymethyl furfural (5-HMF), and results in formation of spherical lignin-like droplets that block pores and/or deposit on the surface of cellulose (Sannigrahi et al. 2011; Hu et al. 2012; Pu et al. 2013; Shinde et al. 2018). Also, it may that the original lignin content of the materials might not have been removed during the treatment. Nevertheless, as a result of hemicellulose and amorphous cellulose removal, the proportion of lignin (original and/or pseudo-lignin) increases, yielding an MFLC material mainly comprising cellulose and lignin. On visual inspection (Supporting Information Figure S1), samples processed at $220{ }^{\circ} \mathrm{C}$ were darker in color than their lower temperature counterparts. This connects well with the ATR-IR absorbance $\left(\sim 1700 \mathrm{~cm}^{-1}\right.$ ) band observed the in darker samples, which may be attributed to condensed tannins and humins and/or migration of lignin from the cell walls to the exterior surface. Thus, the absorbance band at approximately $1700 \mathrm{~cm}^{-1}$ may correspond to carbonyl stretching vibrations associated with ferulic and para-coumaric acid (Zhao et al. 2011; Chandra et al. 2016; Liu et al. 2017). A similar effect of microwave processing temperature with respect to changes in functional groups for $\mathrm{AH}$, either untreated $(\mathrm{AH})$ or pretreated (AHET, AHHP), was noted. Subtle changes 
include a stronger carbonyl absorbance band, which persists up to $170{ }^{\circ} \mathrm{C}$.

Crystallinity index

The CI for all types of MFLC produced (Table 4) increases with increasing temperature. CP MFLC (63.1-65.7\%) exhibits the highest CI. Interestingly, CP MFLCs have the lowest CI at $120{ }^{\circ} \mathrm{C}$ but exhibit the highest crystallinity at $220{ }^{\circ} \mathrm{C}$. For example, the CI of CPHP at $120{ }^{\circ} \mathrm{C}$ changes from 17.1 to $65.7 \%$ at $220{ }^{\circ} \mathrm{C}$, equating to a difference of $48.6 \%$. At $120{ }^{\circ} \mathrm{C}$, the AH samples possess crystallinity indexes from 36.6 to $45.8 \%$ and increase to $54.4-61.5 \%$ at $220{ }^{\circ} \mathrm{C}$. The difference from the initial $\left(120^{\circ} \mathrm{C}\right)$ to final temperature $\left(220{ }^{\circ} \mathrm{C}\right)$ is far less drastic; for example, AHHP shows a difference of $9.4 \%$. Thus, the constituents within $\mathrm{CP}$, irrespective of pretreatment or not, are more sensitive to leaching under microwave hydrolysis than are AH. This is in good agreement with the greater spread of hydrolysis reactions occurring for $\mathrm{CP}$ than $\mathrm{AH}$, as commented earlier. Besides, a greater extent of hemicellulosic matter and amorphous cellulose is lost giving a higher final proportion of crystalline cellulose.

Interestingly, as shown in Table 1, the hemicellulose and cellulose composition of neat $\mathrm{CP}$ and $\mathrm{AH}$ is very similar; the only difference being the lignin content, which is significantly higher in $\mathrm{AH}$. Thus, the higher amount of lignin in AH may be shielding or blocking the hydrolysis of hemicellulose and amorphous cellulose which hinders the defibrillation process (Ämmälä et al. 2019).
The XRD patterns for all samples at different stages of treatment are shown in Supporting Information, Figure S3. It is important to note that the XRD patterns are of processed lignocellulosic biomass that still contains some bio-minerals, lignin and hemicellulosic matter. The MFLC samples have not been adulterated in away so as to produce 'pure' cellulose. Thus, the XRD patterns are atypical of 'pure' cellulose. The tentative assignments of the XRD patterns of MFLC processed at 170 and $220{ }^{\circ} \mathrm{C}$ suggest cellulose $\mathrm{I}_{\beta}$, with reflections at $14.8^{\circ}, 16^{\circ}, 22.6^{\circ}, 34.5^{\circ}(2 \theta)$ corresponding to possible Miller indices of (1-10), (110), (200) and (004), respectively (Poletto et al. 2013; French 2014; Kafle et al. 2014; Novo et al. 2015). The sharp peaks at $14.6^{\circ}, 24.3^{\circ}$ and $30^{\circ}$, as shown in Supporting Information Figure S3 $\mathrm{B}$, tentatively suggest the existence of kaolinite $\left(\mathrm{Al}_{2} \mathrm{Si}_{2} \mathrm{O}_{5} \cdot(\mathrm{OH})_{4} \cdot \mathrm{H}_{2} \mathrm{O}\right)$, cristobalite $\left(\mathrm{SiO}_{2}\right)$, and apatite $\left(\mathrm{Ca}_{5}\left(\mathrm{PO}_{4}\right)_{3}(\mathrm{~F}, \mathrm{Cl}, \mathrm{OH})\right.$; i.e., biominerals which were absorbed from soil by the plant (Tazaki et al. 2017). Calcium oxalate was also detected in the MFC of citrus peels prepared via acidfree MHT (de Melo et al. 2017). However, further investigations are been conducted to ascertain the identity of these signals including checking for possible grease contamination of the sample holders.

\section{Thermal stability}

Thermogravimetric analysis (TGA) was performed to investigate the thermal stability of cellulose under $\mathrm{N}_{2}$ gas. The decomposition profiles with respect to temperature are shown in Supporting Information Figure $\mathrm{S} 4$ and the maximum thermal degradation temperature of cellulose for each sample is

Table 4 Crystallinity Index of CP and AH MFLC. Results are presented as mean \pm standard deviation ( $\mathrm{n}=3$ samples)

\begin{tabular}{llll}
\hline MFCs & \multicolumn{2}{l}{ Crystallinity index $(\%)$} & 220 \\
\cline { 2 - 4 } & 120 & 170 & $63.1 \pm 2.3(\mathrm{a})$ \\
CP & $12.7 \pm 2.8(\mathrm{~h})$ & $41.3 \pm 2.8(\mathrm{e})$ & $63.9 \pm 1.8(\mathrm{a})$ \\
CPET & $18.3 \pm 2.4(\mathrm{~g})$ & $44.7 \pm 2.1(\mathrm{~d}, \mathrm{e})$ & $65.7 \pm 3.6(\mathrm{a})$ \\
CPHP & $17.1 \pm 2.7(\mathrm{~g})$ & $50.6 \pm 2.3(\mathrm{c})$ & $54.4 \pm 1.5(\mathrm{~b}, \mathrm{c})$ \\
AH & $36.6 \pm 1.9(\mathrm{f})$ & $42.7 \pm 3.9(\mathrm{~d}, \mathrm{e})$ & $61.5 \pm 1.6(\mathrm{~b})$ \\
AHET & $45.2 \pm 2.4(\mathrm{~d}, \mathrm{e})$ & $45.4 \pm 3.6(\mathrm{~d}, \mathrm{e})$ & $55.2 \pm 3.5(\mathrm{~b}, \mathrm{c})$ \\
AHHP & $45.8 \pm 1.8(\mathrm{~d})$ & $53.2 \pm 2.8(\mathrm{~b}, \mathrm{c})$ & \\
\hline
\end{tabular}

Letters show statistically significant different groups with $95 \%$ confidence. Values not sharing the same letter in each row and/or column are statistically different 
summarized in Table 5. Thermal depolymerization occurs in multiple stages depending on the thermal stability of each structural component and its proportion in the biomass (Chandra et al. 2016). The initial mass loss seen in all samples from 60 to $160{ }^{\circ} \mathrm{C}$ can be attributed to the vaporization of water and/or volatiles (moisture content) from the biomaterial, amounting to approximately $10 \mathrm{wt} \%$. There is a distinct difference in the degradation of $\mathrm{CP}$ with respect to $\mathrm{AH}$. $\mathrm{AH}$ showed an intense thermal event between 170 and $220{ }^{\circ} \mathrm{C}$, which may be due to pectinaceous-like matter or an unidentified high-molecular-weight flavonoid or tannin-like-polyphenol (see Supporting Information Figure S4 DEF) (Esfahlan et al. 2010). This thermal event is not seen in CP. Thereafter, both cassava peel (CP, CPET and CPHP) and almond hull (AH, AHET and AHHP) show a thermal event approximately at 200-220 ${ }^{\circ} \mathrm{C}$, which is more akin to the decomposition of pectinaceous matter (Liu et al. 2015; Matharu et al. 2016b). This thermal event is much weaker for CP, particularly for MFLC pretreated with ethanol. The next major thermal event occurs in the region 298-372 ${ }^{\circ} \mathrm{C}$, characteristic of the decomposition of a mixture of hemicellulose and cellulose (Poletto et al. 2014). This decomposition temperature moves toward higher temperatures with respect to increasing microwave temperature. The samples tend toward increasing crystallinity correlating well with the CI data reported earlier.

Hemicellulose is more readily hydrolyzed than cellulose due to its amorphous structure, while cellulose has a long crystalline chain of glucose polymer, enhancing its thermal stability (Poletto et al. 2012). A notable shoulder, corresponding to the depolymerization of hemicellulose in the untreated $\mathrm{AH}$ (the raw fibers) appears at $225-290{ }^{\circ} \mathrm{C}$ (Supporting Information Figure S4 D) and disappears with pretreatment. Meanwhile, the lignin decomposition occurs from 250 to $500{ }^{\circ} \mathrm{C}$. The thermal decomposition of lignin is substantial due to the cross-linking of phenylpropane units and other high molecular weight groups (Yang et al. 2006; Poletto et al. 2014).

Interestingly, for all $\mathrm{CP}$ samples processed at $220{ }^{\circ} \mathrm{C}(\mathrm{CP}, \mathrm{CPET}$ and $\mathrm{CPHP})$, there appears to be a significant change in the amount of residue left at $625^{\circ} \mathrm{C}$ as can be seen in Supporting Information Figure S4 (ABC). Samples processed at 120 and $170{ }^{\circ} \mathrm{C}$ (and neat $\mathrm{CP}$ ) afford $20-25 \mathrm{wt} \%$ residue, whilst at $220{ }^{\circ} \mathrm{C}$, roughly $45 \mathrm{wt} \%$ of the residue remains. This material may have undergone significant hydrolytic pyrolysis to furnish a pseudochar or pseudolignin-like material. As discussed previously, a substantial darkening of samples processed at $220{ }^{\circ} \mathrm{C}$ is observed. This considerable change was not found in $\mathrm{AH}$ samples and the residue content plateaued at around $35 \mathrm{wt} \%$. This correlates well with the more significant amount of lignin in $\mathrm{AH}$ than in $\mathrm{CP}$.

\section{${ }^{13} \mathrm{C}$ Solid-state CPMAS NMR analysis}

Table 6 summarizes the deconvoluted chemical shift signals for the anhydroglucose portion of cellulose in neat $\mathrm{CP}$, neat $\mathrm{AH}$, ethanol pretreated (CPET or AHET), heptane pretreated (CPHP or AHHP) and their respective MFLCs obtained at 120, 170 and $220{ }^{\circ} \mathrm{C}$. The corresponding full ${ }^{13} \mathrm{C}$ CPMAS NMR spectra are shown in Supporting Information

Table 5 Thermal stability cellulose of CP and AH. Results are presented as mean \pm standard deviation ( $\mathrm{n}=3$ samples)

\begin{tabular}{lllll}
\hline Cellulosic sample & \multicolumn{4}{l}{ Cellulose decomposition temperature $\left({ }^{\circ} \mathrm{C}\right)$} \\
\cline { 2 - 5 } & Native & 120 & 170 & 220 \\
\hline CP & $299.40 \pm 2.22(\mathrm{k})$ & $306.83 \pm 3.19(\mathrm{i}, \mathrm{j})$ & $358.20 \pm 3.64(\mathrm{c}, \mathrm{d}, \mathrm{e})$ & $372.13 \pm 3.98(\mathrm{a})$ \\
CPET & $304.50 \pm 3.84(\mathrm{i}, \mathrm{j}, \mathrm{k})$ & $320.34 \pm 2.43(\mathrm{~h})$ & $360.28 \pm 3.92(\mathrm{c}, \mathrm{d})$ & $369.26 \pm 5.26(\mathrm{a}, \mathrm{b})$ \\
CPHP & $298.17 \pm 4.63(\mathrm{k})$ & $309.36 \pm 4.66(\mathrm{i})$ & $362.17 \pm 2.29(\mathrm{c})$ & $374.15 \pm 3.99(\mathrm{a})$ \\
AH & $303.21 \pm 5.70(\mathrm{i}, \mathrm{j}, \mathrm{k})$ & $347.53 \pm 2.61(\mathrm{f}, \mathrm{g})$ & $351.68 \pm 5.58(\mathrm{e}, \mathrm{f}, \mathrm{g})$ & $363.28 \pm 2.55(\mathrm{~b}, \mathrm{c})$ \\
AHET & $300.42 \pm 4.87(\mathrm{j}, \mathrm{k})$ & $346.18 \pm 4.03(\mathrm{~g})$ & $346.77 \pm 4.59(\mathrm{f}, \mathrm{g})$ & $364.03 \pm 4.37(\mathrm{~b}, \mathrm{c})$ \\
AHHP & $304.12 \pm 6.41(\mathrm{i}, \mathrm{j}, \mathrm{k})$ & $349.79 \pm 2.56(\mathrm{f}, \mathrm{g})$ & $353.56 \pm 4.98(\mathrm{~d}, \mathrm{e}, \mathrm{f})$ & $359.43 \pm 4.22(\mathrm{c}, \mathrm{d})$ \\
\hline
\end{tabular}

Letters show statistically significant different groups with $95 \%$ confidence. Values not sharing the same letter in each row and/or column are statistically different 
Table 6 Deconvoluted ${ }^{13} \mathrm{C}$ CPMAS NMR spectra of $\mathrm{CP}$ and $\mathrm{AH}$ MFLCs

\begin{tabular}{|c|c|c|c|c|c|c|}
\hline \multirow[t]{2}{*}{ Cellulosic samples } & \multicolumn{6}{|c|}{ Resonances (ppm) } \\
\hline & $\mathrm{C} 1$ & $\mathrm{C} 4$ & $\mathrm{C} 2$ & $\mathrm{C} 3$ & $\mathrm{C} 5$ & C6 \\
\hline $\mathrm{CP}$ & $104.65,100.44$ & 82.75 & - & 72.62 & 75.76 & $62.66,60.48$ \\
\hline CP120 & $105.71,103.34$ & 82.86 & - & 72.74 & 75.74 & $62.98,60.63$ \\
\hline CP170 & 104.41 & $88.91,82.85$ & - & 72.69 & 75.37 & $65.53,62.84$ \\
\hline CP220 & $106.16,104.69$ & $88.98,84.83$ & 71.96 & 72.99 & 75.33 & $65.47,63.39$ \\
\hline CPET & $104.63,100.76$ & 82.94 & - & 72.64 & 75.46 & 62.67 \\
\hline CPET120 & 103.52 & 82.97 & - & 72.66 & 75.09 & $62.94,60.92$ \\
\hline CPET170 & 105.18 & $89.22,83.75$ & - & 72.66 & 75.34 & $65.42,62.70$ \\
\hline CPET220 & $106.05,104.60$ & $88.94,84.04$ & 71.89 & 72.89 & 75.29 & $65.53,65.26$ \\
\hline СPHP & $104.24,100.33$ & 82.73 & - & 72.65 & 75.65 & 62.58 \\
\hline CPHP120 & 103.50 & 82.88 & - & 72.74 & 75.22 & 61.90 \\
\hline CPHP170 & $105.90,104.54$ & $88.95,84.33$ & - & 72.57 & 75.31 & $65.51,62.73$ \\
\hline CPHP220 & $106.03,104.60$ & $89.33,84.26$ & 71.90 & 73.02 & 75.28 & $65.52,63.32$ \\
\hline $\mathrm{AH}$ & $105.26,99.28$ & 83.34 & - & 72.32 & 75.23 & $65.15,62.67$ \\
\hline AH120 & 105.28 & 89.1283 .73 & - & 72.55 & 75.16 & $65.20,62.94$ \\
\hline AH170 & 105.36 & $89.14,83.95$ & - & 72.29 & 75.12 & $65.28,62.63$ \\
\hline AH220 & $106.01,104.61$ & $89.07,84.15$ & 71.84 & 72.87 & 75.33 & $65.42,62.74$ \\
\hline AHET & $105.13,98.87$ & 83.87 & - & 72.35 & 75.32 & $65.34,63.04$ \\
\hline AHET120 & 105.27 & $88.97,83.34$ & - & 72.29 & 75.16 & $65.25,62.63$ \\
\hline AHET170 & 105.51 & $89.07,82.86$ & & 72.40 & 75.28 & $65.29,62.54$ \\
\hline AHET220 & $106.00,104.60$ & $89.13,83.95$ & 71.80 & 72.87 & 75.23 & $65.33,62.73$ \\
\hline AHHP & $105.45,99.04$ & 83.47 & - & 72.39 & 75.41 & 65.13 \\
\hline AHHP120 & 105.85 & $89.40,84.03$ & - & 72.61 & 75.51 & $65.39,62.90$ \\
\hline АНHР170 & 105.58 & $89.27,83.91$ & - & 72.56 & 75.46 & $65.38,62.78$ \\
\hline AHHP220 & $105.92,104.70$ & $89.04,84.12$ & 71.91 & 72.85 & 75.4 & $65.99,62.99$ \\
\hline
\end{tabular}

Figure S5, which reveal additional resonances at approx. 165-180 ppm, 110-160 ppm and 25-40 ppm.

The resonances identified in Table 6 are characteristic of an anhydroglucose unit representative of carbohydrate polymers. For example, starch shows resonances at $\mathrm{C} 1$ (100 ppm), C4 (82 ppm) C2, C3, C5 (74-70 ppm), and C6 (61 ppm). (Guo et al. 2016; Yu et al. 2017) CP120 shows a series of resonances: C1 (103 ppm), C4 (82 ppm), C2,3,5 (72-74 ppm), and C6 (64 ppm), possibly corresponding to hemicellulose composed by $1-4$-linked $\beta$-D-xylopyranose units. (Lyu et al. 2010) The neat AH appeared to contain 4-Omethyl glucuronic acid from hemicellulose, where the chemical carbon include C1 (98 ppm), C4 (83 ppm) and C3 (73 ppm) (Lyu et al. 2010). The chemical shifts of crystalline cellulose $\mathrm{I}_{\beta}$ signals are $\mathrm{C} 1$ (106 and $104 \mathrm{ppm}), \mathrm{C} 2$ (71 ppm), C3 (74.9 ppm), C4 (88.9 ppm), C5 (72 ppm), C6 (65 ppm) (Kono and Numata 2006). These resonances correspond to MFLC samples produced $220^{\circ} \mathrm{C}$ (Table 6). Effective removal of hemicellulose from cellulose and the increase in the degree of crystallinity can be observed from the resonances for $\mathrm{C} 4(82-89 \mathrm{ppm})$ and $\mathrm{C} 6$ (62-66 ppm), which are indicative of amorphous and crystalline cellulose (Supporting Information Figure S5). By increasing the microwave processing temperature from 120 to $220{ }^{\circ} \mathrm{C}$, these resonances start to split into two and become sharper. The resonances associated with amorphous cellulose decrease in intensity, whilst those for crystalline cellulose increase. (Park et al. 2010) Additionally, the $\mathrm{C} 2, \mathrm{C} 3$ and $\mathrm{C} 5$ resonances also become sharper when the temperature increases. For example, a clear resonance is observed at approx. $71 \mathrm{ppm}$ in all samples processed at $220^{\circ} \mathrm{C}$. Interestingly, CP MFLC at $220{ }^{\circ} \mathrm{C}$, the broad resonances at $173-178 \mathrm{ppm}$, 160-110 ppm, and 21-30 ppm may be attributed to lignin and/or pseudolignins. (Ralph and Landucci 
2010; Balakshin and Capanema 2015; Ladesov et al. 2018) Again, this supports our previous data (crystallinity index, ATR-IR and TGA) and the notion that above $170{ }^{\circ} \mathrm{C}$ significant leaching of amorphous cellulose takes place coupled with lignin either moving to surface or decomposition of cellulose to afford pseudolignins, which overall results in a MFLC material.

Of particular note on comparing the differences in the spectra between neat $\mathrm{CP}$ and $\mathrm{AH}$ is the significant presence of resonances in the aromatic region $(110-160 \mathrm{ppm})$ and alkyl region $(20-40 \mathrm{ppm})$ in the latter. This analysis may also confirm our original compositional data analysis in Table 1, which revealed that neat $\mathrm{AH}$ contains significantly more lignin (ca. $11 \mathrm{wt} \%$ ) compared to CP (ca. $3 \mathrm{wt} \%$ ). The resonances for lignin remain for all $\mathrm{AH}$ samples processed, and $\mathrm{CP}$ at $220{ }^{\circ} \mathrm{C}$ will also include resonances associated with pseudolignins.

\section{TEM analysis}

TEM photographs provide useful insights into the classification of defibrillated celluloses. According to TAPPI WI3021 (Kargarzadeh et al. 2017; Hazwan Hussin et al. 2019), the hierarchical structure of cellulose fibers can be classified into nano-objects [cellulose nanocrystal (CNC), cellulose nanofibril (CNF)] and nanostructured cellulose [cellulose microcrystal (CMC), cellulose microfibril (CMF)]. $\mathrm{CNC}$ is pure crystalline fibers with $\mathrm{W}=3-10 \mathrm{~nm}$ and aspect ratio $\mathrm{L} / \mathrm{W}=5-50$, while $\mathrm{CNF}$ is fibrous cellulose of plant material that contains both crystalline and amorphous regions $(\mathrm{W}=5-30 \mathrm{~nm}$, aspect ratio $\mathrm{L} / \mathrm{W}>50)$. Cellulose microcrystal (CMC) is depolymerized into high purity cellulose $(\mathrm{DP}<400)$ with a structured bundle of cellulose (W 10-15 $\mu \mathrm{m}$, aspect ratio $\mathrm{L} / \mathrm{W}<2$ ). In contrast, $\mathrm{CMF}$ or microfibrillated cellulose (MFC) in purified wood or non-wood yields multiple elementary fibrils with crystalline and amorphous regions, typically containing residual hemicellulose $\quad(\mathrm{W}=10-100 \mathrm{~nm}, \quad \mathrm{~L}=0.5-10 \mu \mathrm{m})$. Microfibrillated lignocellulose (MFLC) is a nonbleached microfiber-like material, rich in cellulose but still containing some lignin (Oliaei et al. 2020).

Figure 1 displays the TEM images for MFLC of $\mathrm{CP}$, CPET and CPHP with respect to microwave temperature processing. The black arrow on each image highlights the microfibril width, as calculated through the ImageJ software. The width of all fibers produced by microwave treatment with operating temperatures between 120 and $220{ }^{\circ} \mathrm{C}$ is relatively similar and below $11 \mathrm{~nm}$. Thus, according to TAPPI WI3021, defibrillation via acid-free MHT produces MFLC. The microfibril is split into smaller aspect ratios (Zhang et al. 2016) and several elementary fibers $(\mathrm{W}<3.5 \mathrm{~nm})$ can be found at a hydrolysis temperature of $170{ }^{\circ} \mathrm{C}$ and above (Chinga-Carrasco 2011; Mishra et al. 2018). Nanocrystal-like or needlelike fibers (lower aspect ratio) (Chen et al. 2015) can be observed from MFLC produced $220{ }^{\circ} \mathrm{C}$ with shorter lengths ranging from 0.5 to $2.7 \mu \mathrm{m}$.

The TEM images of microfibrils obtained from microwave processing of AH are shown in Fig. 2. The average widths measured for AH MFLC were between 6.5 and $2.0 \mathrm{~nm}$. Similar to $\mathrm{CP}$ reported earlier, increasing microwave processing temperature induces defibrillation to microfibrils to nanofibers and nanocrystals. Some residual amorphous matter entangled amongst the fibers was also present. The dark grey amorphous clusters are presumed to be pseudolignin or lignin surrounding the fibers. These recalcitrant clusters composed mainly of residual lignin-like fragments, were hydrolyzed at high temperatures (De Melo et al. 2017).

\section{Hydrolysate analysis}

HPLC analysis on the resulting aqueous fraction (hydrolysate) after microwave treatment was performed to gain an insight into the chemical hydrolysis of biomass. As shown in Supporting Information Figure S6, the hydrolysates of all CP samples did not contain galacturonic acid, a sugar acid commensurate with pectinaceous matter (Flutto 2003). It is hypothesized that the effect of ethanol pretreatment could have removed partially removed xylose and glucose, because only a small amount of these were detected in the CPET120 hydrolysate. Even though most sugars are insoluble in cold or ambient temperature ethanol, Soxhlet extraction works near the boiling point of the solvent. This implies that the ethanol never reached its saturation temperature due to the recycling of fresh ethanol from the reflux condenser (Luque de Castro and García Ayuso 2000). Neat CP consists of a polymer of $\alpha$-glucose from starch with concentrations of 42-60.6\% (w/w) (Ratnayake and Jackson 2003; Montagnac et al. 2009; Souto et al. 2016) and is 


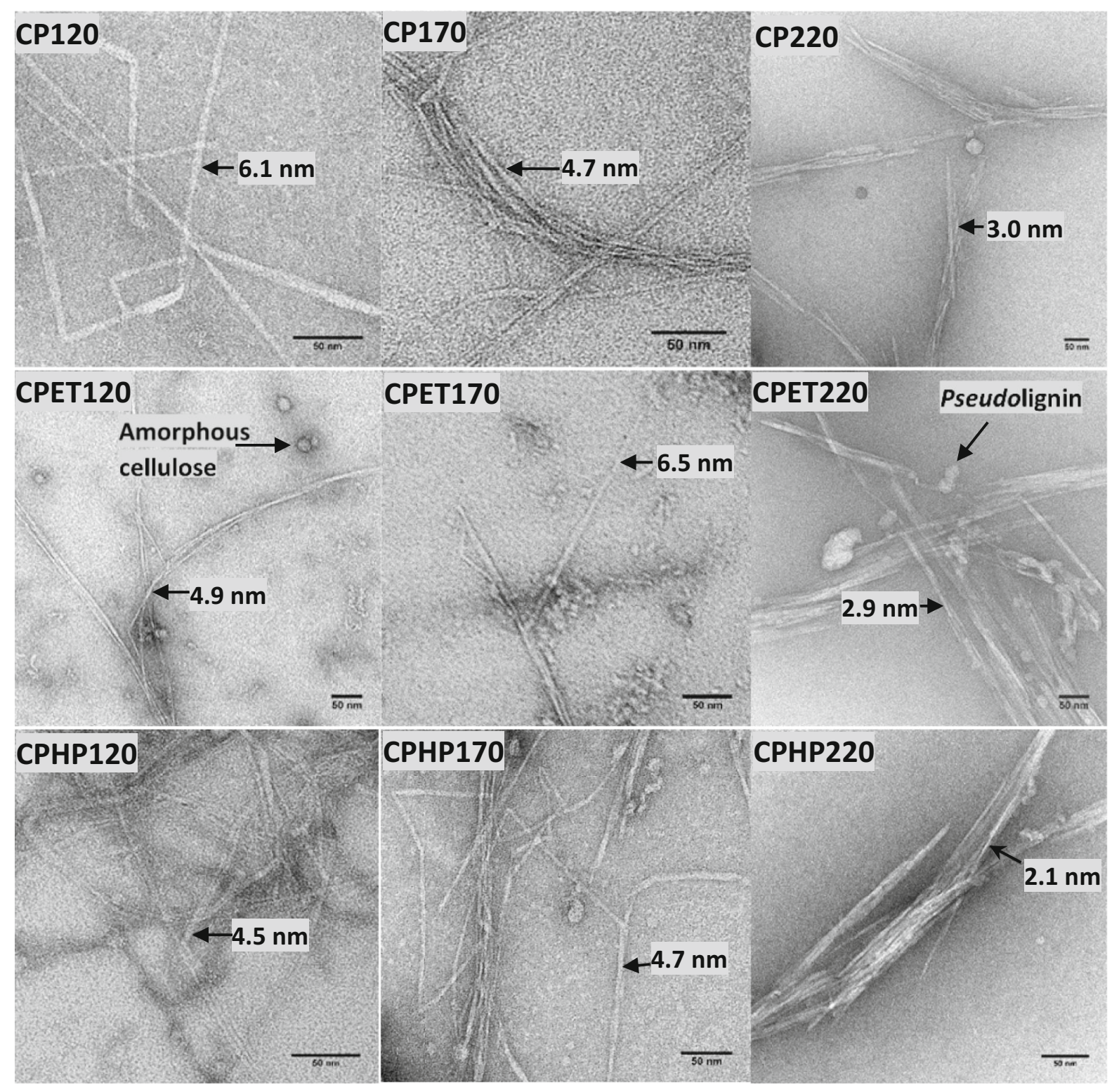

Fig. 1 TEM images of CP, CPET and CPHP MFLCs at different processing temperatures

xylose-rich ( $\mathrm{Lu}$ et al. 2017). AH hydrolysate from post-ethanol pretreatment between 120 and $170{ }^{\circ} \mathrm{C}$ showed the highest concentration of rhamnose and galacturonic acid compared to other hydrolysates (Supporting Information Figure S7). In this aqueous fraction, the xylose monomer was also not detected. The amounts of galacturonic acid (the main monomer in pectin) correlate well with the TGA data discussed earlier, as these species can be found in the hydrolysate of $\mathrm{AH}$ only at a temperature below $170{ }^{\circ} \mathrm{C}$ (Chan et al. 2017).

Interestingly, the sugar analysis for the $\mathrm{AH}$ hydrolysate with heptane pretreatment did not identify the presence of rhamnose or galacturonic acid at a temperature of $120{ }^{\circ} \mathrm{C}$. The extracted compounds from the lipids present in the biomass may be capable of altering the $p \mathrm{Ka}$ of the reaction medium (e.g., from short/long fatty acid and rhamnolipids) and then, possibly the water contained in the medium may affect 


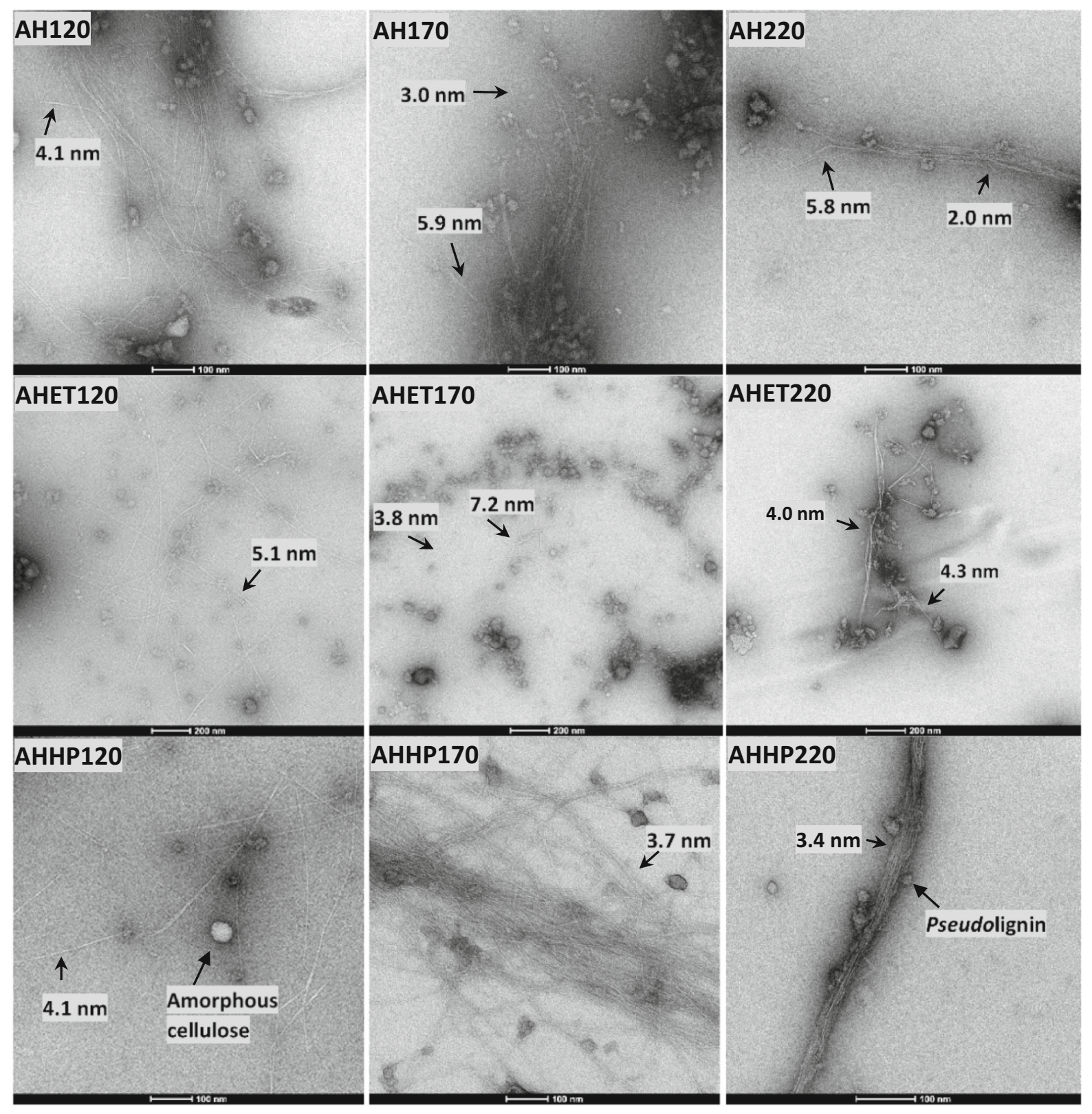

Fig. 2 TEM images of almond hull MFLCs produced at different temperatures

the polymerization of the sugar acids and rhamnose during Soxhlet extraction (Kobayashi et al. 2017; Soltani Dashtbozorg et al. 2019).

Scissoring of amorphous cellulose and hemicellulose compounds depends on the operating microwave temperature (Xia et al. 2016; De Melo et al. 2017). Mostly glucose and xylose were identified in the hydrolysate produced at temperatures below $170{ }^{\circ} \mathrm{C}$. Hydrothermal conversion after $170{ }^{\circ} \mathrm{C}$ resulted in the generation of by-products, such as formic acid, levulinic acid, and acetic acid. The formation of formic acid and levulinic acid yielded from glucose degradation, while acetic acid formation was attributed to xylose dehydration, associated with the lower amount of xylose as the temperature increases (Yoon et al. 2014; Delbecq et al. 2018). Besides, 5-hydroxymethyl furfural (5-HMF), furfural and levoglucosan (especially at high temperature) were more abundant 
in the $\mathrm{CP}$ than in the $\mathrm{AH}$ hydrolysates. These species were identified as value-added chemical products from the conversion of derivative sugars (Danon et al. 2014; Cao et al. 2015; Sweygers et al. 2018). Phenolic compounds were not detected in the hydrolysate, suggesting that either lignin was not substantially depolymerized during the treatment or its depolymerization only gave water-soluble ligno-oligomers. Given these data, Fig. 3 shows a possible reaction pathway for cellulose and hemicellulose conversions to these value-added chemical products under the operating conditions used in this work.

\section{Zeta potential}

The zeta potential describes the net surface charge of a colloid dispersed in water and can be used to determine the physical stability of an emulsion or suspension (Sabbah and Esposito 2016). A high zeta potential value indicates electrostatic repulsion between particles, preventing aggregation (high colloidal stability $\zeta= \pm 40-60 \mathrm{mV}$ ). Conversely, a low zeta potential value colloid means that the suspended particles have high electrostatic attraction and weak repulsion, thus, tend to flocculate, especially over extended periods (rapid coagulation, $\zeta= \pm 0-5 \mathrm{mV}$ ) (Tholstrup Sejersen et al. 2007; Pelissari et al. 2014).

As shown in Fig. 4, microwave processing temperature directly affects the zeta potential in neutral water ( $\mathrm{pH} 7$ ), i.e., increasing temperature decreases the zeta potential until a temperature of $170{ }^{\circ} \mathrm{C}$ is reached, whereafter, the zeta potential remains relatively constant. All fibers exhibited a negative zeta potential in which AH MFLC consistently displayed a higher zeta potential than $\mathrm{CP}$ fibers. At a hydrolysis temperature of $120^{\circ} \mathrm{C}$, the zeta potential of $\mathrm{CP}$ ranged between -0.8 and $-1.2 \mathrm{mV}$. For $\mathrm{AH}$ non-treatment and heptane treatment, it was quite similar between -5.4 and $-6.5 \mathrm{mV}$, except for the ethanol treatment in which the zeta potential turned to be more negative at

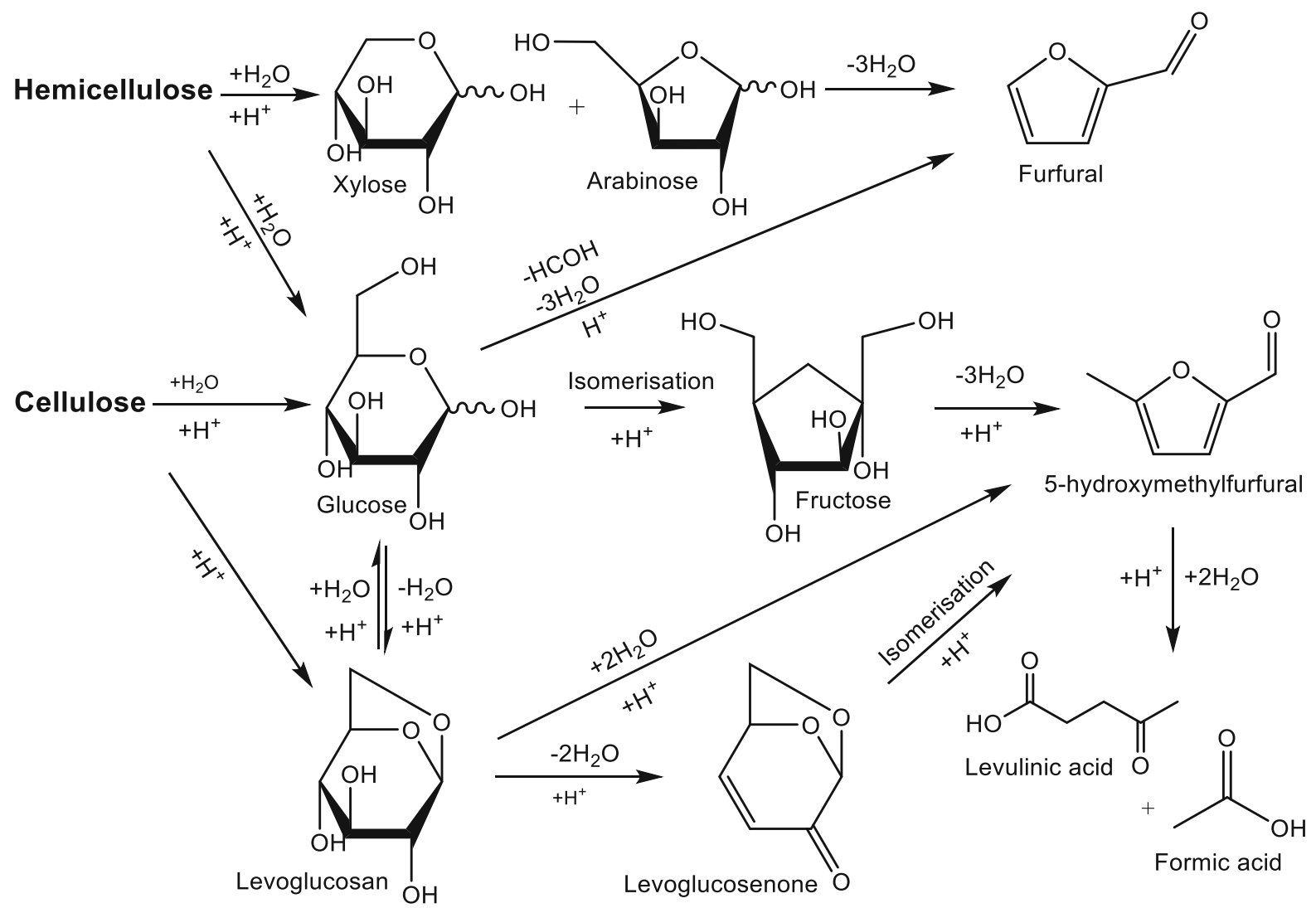

Fig. 3 Sugar conversion pathways to furfural, 5-HMF, levulinic acid and formic acid (Dhepe and Sahu 2010; Cao et al. 2015; Herbst and Janiak 2016) 


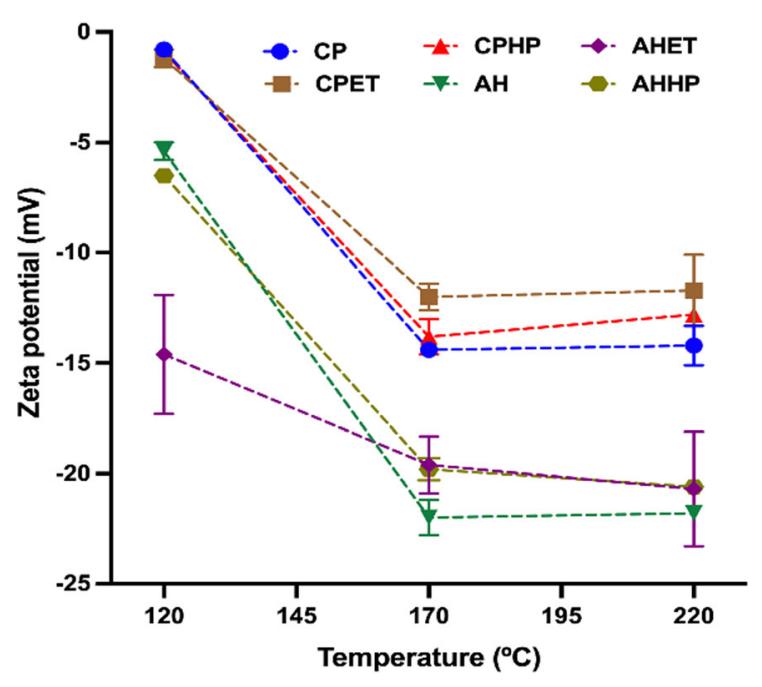

Fig. 4 Zeta potential of $\mathrm{CP}$ and AH MFLCs at $\mathrm{pH}$ neutral. Bars represents standard deviations ( $\mathrm{n}=3$ measurements)

the temperature of $120^{\circ} \mathrm{C}(-14.6 \mathrm{mV})$. A hydrothermal treatment at 170 and $220{ }^{\circ} \mathrm{C}$ caused a slightly significant change to the zeta potential of pretreated and non-pretreated fibers, where $\mathrm{CP}$ ranged between - 11.7 and $-14.4 \mathrm{mV}$ and AH between - 19.6 and - $22.0 \mathrm{mV}$. The more negative value of zeta potential for MFLC in water, the higher is the repulsion between particles, thus increasing the hydrophobic behavior (Huang et al. 2017).

\section{MFLC-based films}

The MFLC derived from $\mathrm{AH}$ and $\mathrm{CP}$ was used to fabricate thin films, shown in Supporting Information Figure S8. The films were prepared using $0.2 \%(\mathrm{w} / \mathrm{v})$ of MFLC dispersed in deionized water and poured into a PTFE membrane filter. From the low-temperature group of MFLCs, only AHET120 successfully made a film compared with the other samples which broke easily when peeled from the PTFE membrane. All films from CP120 MFLC became stuck to the membrane, were brittle, cracking very easily upon drying (not shown). However, all MFLCs from microwave hydrolysis at 170 and $220{ }^{\circ} \mathrm{C}$ quickly dried and formed a structured film. This could be related to decreased water retention and swelling of the fibers with increasing temperature during the hydrolysis process (Matharu et al. 2018). The fibers tend to increase hydrophobic character and hornify as the hydrolysis temperature increases (Diniz et al.
2004). Intermolecular interactions, including electrostatic, hydrogen bonding, and hydrophobic interaction, influence film structure stability (Garcia et al. 2016). These results indicate that the microwave treatment was the driving force for film formation. The transparency of the films depended on the treatment of the fiber source. This can be seen in the aforementioned image, i.e., the light brown films at lowtemperature turned to black films at high-temperature. Black films indicate a high lignin content of MFLC with hydrophobic characteristics (Jang et al. 2020).

The SEM analysis of MFLC films produced at low temperatures showed a rough texture [see Supporting Information Figure S9 (AH) and Figure S10 (CP)], visually similar to a chunk of wood-like material or flax fibers and bundles of fibers crossing over each other. For example, the surface and cross-section of AHET120 and AHHP120 films with the width ranging between 9 and $18 \mu \mathrm{m}$, roughly. In comparison, fiber bundles of sugar palm cellulose produced via the delignification and mercerization methods have a width of approximately $11.8 \mu \mathrm{m}$ (Ilyas et al. 2019). Surface roughness decreased with increasing temperature. The MFLC produced at high temperatures generated a visibly smoother film than films produced using materials prepared at low temperatures. Incomplete removal of non-cellulosic materials may have influenced the roughness of the film, and many fibril bundles result in the surface being irregular. There is a correlation between the preparation of bio-film and zeta potential. If the particles suspended in the water (mixture or single component) have a zeta potential between lower than $+10 \mathrm{mV}$ or less negative than $-10 \mathrm{mV}$, then the film will become unstable and tough (Sabbah and Esposito 2016). This conclusion is in good agreement with our zeta potential results, wherein the MFLC 120 group from AHET120 $(\zeta=-14.6 \mathrm{mV}$ ) showed the lowest zeta potentials and could make good films (not easily ripped when peeled from membrane).

\section{Hydrogel formation}

The term 'hydrogel' describes a swollen polymer that retains a large amount of water (at least $90 \%$ of water) by maintaining a three-dimensional (3D) network of hydrophilic linkages suspended in an aqueous solution (Cha et al. 2012; Bahram et al. 2016). Forming a gel can be predicted and controlled from polymer 
structure, molecular symmetry and medium by the presence of hydrophilic groups attached to the polymeric backbone such as $-\mathrm{COOH},-\mathrm{OH},-\mathrm{NH}_{2},-$ $\mathrm{CONH}_{2},-\mathrm{CONH}$ and $-\mathrm{SO}_{3} \mathrm{H}$ (Bahram et al. 2016; Shanks and Pardo 2018).

Cellulose alone is not soluble in water, and most cellulose-based hydrogels are generated within a hybrid system by surface modification, e.g., methylcellulose, carboxymethyl cellulose, hydroxyethyl cellulose (Koschella et al. 2011; De France et al. 2017; Kabir et al. 2018; Shanks and Pardo 2018). To maximize the amount of trapped water, the sol-gel phase transition is subjected to physical and or chemical stimuli. Physical stimuli include heating, magnetic field, light, pressure, sonication, and homogenization, while chemical stimuli include $\mathrm{pH}$ mediumresponsive, via ions of salt addition and chemical addition network trigger (Soares et al. 2009, 2014; Ullah et al. 2015; Bahram et al. 2016; De France et al. 2017; Chatterjee and Chi-leung Hui 2019). The chemical network is built through covalent bonds to improve stability and strengthening of the network when space is filled with water. At the same time, physical forces cause entanglement or junction of fibers via ionic bonding, hydrogen bonding, or van der Waals interactions where the molecular self-assembly depends on environment changes helping to trap the liquid (Ciolacu and Suflet 2018).

The physical stimuli used in the present work to stimulate the formation of hydrogel comprised an initial homogenization step for $5 \mathrm{~min}$, followed by an ultrasound treatment for $10 \mathrm{~min}$, with an amplitude of $65 \%$. The MFLC hydrogel was produced in this work without any chemical surface modification. The minimum concentration of AH MFLC required to form a stable hydrogel was identified to be around $2 \%$ (w/v) for AH120 and AHHP120, whilst for AHET120, the minimum concentration was $3 \%(\mathrm{w} / \mathrm{v})$, determined by an inversion test (see Supporting Information Figure S11). Interestingly, CP120 and CPET120 produced hydrogels at significantly higher concentrations of $7 \%(\mathrm{w} / \mathrm{v})$, whilst CPHP120 was able to form a gel at 5\% (w/v) (Supporting Information Figure S12). The high concentration of gelation in $\mathrm{CP}$ could be related to the absence of galacturonic acid and/or pectinaceous matter (as earlier discussed in HPLC analysis) in these samples. The presence of galacturonic acid/pectinaceous matter was evident in $\mathrm{AH}$ MFLC samples but these also contained a significant amount of lignin or condensed tannins (TGA analysis). Furthermore, the AH hydrolysates contained monomeric sugar units of rhamnose, another key fragment within pectin (Thakur and Thakur 2016). Electrostatic (or ionic) cross-linked pectin builds strong networks with covalent polysaccharide domain bonds (Chan et al. 2017). A small number of anionic surface charges from residual hemicellulose made a firm gel, forming the entangled network at a lower concentration when compared to pure nanocrystalline cellulose (CNC) itself (De France et al. 2017).

MFLC produced at $120{ }^{\circ} \mathrm{C}$ exhibited excellent dispersion in water, demonstrating a higher hydrophilic interaction than the MFLC produced at $170{ }^{\circ} \mathrm{C}$ and above, which tended to be less hydrophilic, resulting in low swelling. Hydrophobicity of MFLC increased with the temperature of hydrolysis. The formation of pseudolignin and/or lignin at high temperature, which has a lower negative surface charge, and it is insoluble in water due to the presence of carbonyl, methoxy and polyaromatic structures, might be responsible for this phenomenon (Sannigrahi et al. 2011; Shinde et al. 2018).

\section{Conclusions}

This work has demonstrated that acid-free microwavehydrothermal is a promising green technology for food waste valorization at relatively low temperatures and very short processing times. Recovery feedstock of CP and the $\mathrm{AH}$ was found to be feasible for biobased materials (MFLC) and chemicals (sugar-rich solutions/value-added chemicals) production. Our results point out that the pretreatment step, the microwave processing temperature and feedstock nature exerted a significant influence on the yields and properties of the MFLCs produced. Increasing the MHT temperature substantially affected the yield of MFLC, crystallinity index, thermal stability and MFLC chemical composition. These changes influenced the gelation capabilities of the materials produced at high temperatures. These materials were capable of producing stable hydrogels with a minimum solid concentration ranging between 2 and $7 \% \mathrm{w} / \mathrm{v}$, regardless of the feedstock or pretreatment. This work demonstrates that the acidfree MHT processing of unavoidable food waste is a facile and promising method to produce MFLC with many potential applications in different sectors, for 
example, adsorption, packaging and the production of nanocomposites and personal care rheology modifiers.

Acknowledgments APS would like to thank Lembaga Pengelola Dana Pendidikan (LPDP) scholarship, Ministry of Finance, Indonesia, for financial support for $\mathrm{PhD}$ study under the guidance of ASM. JR would like to express his gratitude to the Spanish Ministry of Science, Innovation and Universities for the Juan de la Cierva fellowships (FJCI-2016-30847 and IJC2018037110-I) awarded. ASM acknowledges the EPSRC (Whole systems understanding of unavoidable food supply chain wastes for re-nutrition EP/P008771/1) for funding TD for Postdoctoral study.

Author Contributions The manuscript was written through the contributions of all authors. All authors have given approval to the final version of the manuscript.

\section{Compliance with ethical standards}

Conflict of interest The authors declare that they have no conflict of interest.

Ethical approval and ethical standards The authors declare no animal studies or human participants were involved in the study. The work is ethically sound.

Open Access This article is licensed under a Creative Commons Attribution 4.0 International License, which permits use, sharing, adaptation, distribution and reproduction in any medium or format, as long as you give appropriate credit to the original author(s) and the source, provide a link to the Creative Commons licence, and indicate if changes were made. The images or other third party material in this article are included in the article's Creative Commons licence, unless indicated otherwise in a credit line to the material. If material is not included in the article's Creative Commons licence and your intended use is not permitted by statutory regulation or exceeds the permitted use, you will need to obtain permission directly from the copyright holder. To view a copy of this licence, visit http://creativecommons.org/licenses/by/4.0/.

\section{References}

Abdul Khalil HPS, Davoudpour Y, Islam MN et al (2014) Production and modification of nanofibrillated cellulose using various mechanical processes: a review. Carbohydr Polym 99:649-665. https://doi.org/10.1016/j.carbpol. 2013.08.069

Aktas T, Thy P, Williams RB et al (2015) Characterization of almond processing residues from the Central Valley of California for thermal conversion. Fuel Process Technol 140:132-147. https://doi.org/10.1016/j.fuproc.2015.08. 030

Ämmälä A, Laitinen O, Sirviö JA, Liimatainen H (2019) Key role of mild sulfonation of pine sawdust in the production of lignin containing microfibrillated cellulose by ultrafine wet grinding. Ind Crops Prod 140:111664. https://doi.org/ 10.1016/j.indcrop.2019.111664

Bahram M, Mohseni N, Moghtader M (2016) An introduction to hydrogels and some recent applications. In: Majee SB (ed) Emerging concepts in analysis and applications of hydrogels. InTech, London, p 13

Balakshin MY, Capanema EA (2015) Comprehensive structural analysis of biorefinery lignins with a quantitative $13 \mathrm{C}$ NMR approach. RSC Adv 5:87187-87199. https://doi.org/ $10.1039 / \mathrm{c} 5 \mathrm{ra} 16649 \mathrm{~g}$

Cao F, Schwartz TJ, McClelland DJ et al (2015) Dehydration of cellulose to levoglucosenone using polar aprotic solvents. Energy Environ Sci 8:1808-1815. https://doi.org/10.1039/ c5ee00353a

Cha R, He Z, Ni Y (2012) Preparation and characterization of thermal/pH-sensitive hydrogel from carboxylated nanocrystalline cellulose. Carbohydr Polym 88:713-718. https://doi.org/10.1016/j.carbpol.2012.01.026

Chan SY, Choo WS, Young DJ, Loh XJ (2017) Pectin as a rheology modifier: origin, structure, commercial production and rheology. Carbohydr Polym 161:118-139. https:// doi.org/10.1016/j.carbpol.2016.12.033

Chandra JCS, George N, Narayanankutty SK (2016) Isolation and characterization of cellulose nanofibrils from arecanut husk fibre. Carbohydr Polym 142:158-166. https://doi.org/ 10.1016/j.carbpol.2016.01.015

Chatterjee S, Chi-leung Hui P (2019) Stimuli-responsive hydrogels: an interdisciplinary overview. In: Popa L, Ghica MV, Dinu-Pîrvu C-E (eds) Hydrogels — smart materials for biomedical applications. IntechOpen, London, p 13

Chen L, Wang Q, Hirth K et al (2015) Tailoring the yield and characteristics of wood cellulose nanocrystals (CNC) using concentrated acid hydrolysis. Cellulose 22:1753-1762. https://doi.org/10.1007/s10570-015-0615-1

Chinga-Carrasco G (2011) Cellulose fibres, nanofibrils and microfibrils: the morphological sequence of MFC components from a plant physiology and fibre technology point of view. Nanoscale Res Lett 6:1-7. https://doi.org/10.1186/ 1556-276X-6-417

Ciolacu DE, Suflet DM (2018) Cellulose-based hydrogels for medical/pharmaceutical applications. In: Popa VI, Volf I (eds) Biomass as renewable raw material to obtain bioproducts of high-tech value. Elsevier, Amsterdam, pp 401-439

Coates J (2006) Interpretation of infrared spectra, a practical approach. In: Meyers RA (ed) Encyclopedia of analytical chemistry. Wiley, Chichester, pp 1-23

Danon B, Marcotullio G, De Jong W (2014) Mechanistic and kinetic aspects of pentose dehydration towards furfural in aqueous media employing homogeneous catalysis. Green Chem 16:39-54. https://doi.org/10.1039/c3gc41351a

De France KJ, Hoare T, Cranston ED (2017) Review of hydrogels and aerogels containing nanocellulose. Chem Mater 29:4609-4631. https://doi.org/10.1021/acs. chemmater.7b00531

De Melo EM, Clark JH, Matharu AS (2017) The Hy-MASS concept: hydrothermal microwave assisted selective scissoring of cellulose for: In situ production of (meso)porous nanocellulose fibrils and crystals. Green Chem 19:3408-3417. https://doi.org/10.1039/c7gc01378g 
Delbecq F, Wang Y, Muralidhara A et al (2018) Hydrolysis of hemicellulose and derivatives-a review of recent advances in the production of furfural. Front Chem 6:1-29. https://doi.org/10.3389/fchem.2018.00146

Dhepe PL, Sahu R (2010) A solid-acid-based process for the conversion of hemicellulose. Green Chem 12:2153-2156. https://doi.org/10.1039/c004128a

Diniz JMBF, Gil MH, Castro JAAM (2004) Hornification-its origin and interpretation in wood pulps. Wood Sci Technol 37:489-494. https://doi.org/10.1007/s00226-003-0216-2

Esfahlan AJ, Jamei R, Esfahlan RJ (2010) The importance of almond (Prunus amygdalus L.) and its by-products. Food Chem 120:349-360. https://doi.org/10.1016/j.foodchem. 2009.09.063

Ewulonu CM, Liu X, Wu M, Yong H (2019) Lignin-containing cellulose nanomaterials: a promising new nanomaterial for numerous applications. J Bioresour Bioprod 4:3-10. https://doi.org/10.21967/jbb.v4i1.186

FAO (2014) Food wastage footprint: full cost-accounting. In: The Food and Agriculture Organization. United Nations. http://www.fao.org/3/a-i3991e.pdf. Accessed 22 Feb 2020

FAO (2018) Food outlook-biannual report on global food markets. In: Global information and early warning. system on food and agriculture. http://www.fao.org/3/CA2320EN/ ca2320en.pdf. Accessed 3 Mar 2020

Ferrandez-Villena M, Ferrandez-Garcia CE, Ortuño TG et al (2019) Study of the utilisation of almond residues for lowcost panels. Agronomy 9:1-10. https://doi.org/10.3390/ agronomy 9120811

Flutto L (2003) PECTINlproperties and determination. In: Second E (ed) Caballero BBT-E of FS and N. Academic Press, Oxford, pp 4440-4449

French AD (2014) Idealized powder diffraction patterns for cellulose polymorphs. Cellulose 21:885-896. https://doi. org/10.1007/s10570-013-0030-4

Garcia MPM, Gómez-Guillén MC, López-Caballero ME, Barbosa-Cánovas GV (2016) Edible films and coatings. CRC Press Taylor, Boca Raton

González JF, González-García CM, Ramiro A et al (2005) Use of almond residues for domestic heating. Study of the combustion parameters in a mural boiler. Fuel Process Technol 86:1351-1368. https://doi.org/10.1016/j.fuproc. 2005.01.022

Guo J, Lian X, Kang H et al (2016) Effects of glutenin in wheat gluten on retrogradation of wheat starch. Eur Food Res Technol 242:1485-1494. https://doi.org/10.1007/s00217016-2649-5

Hazwan Hussin M, Trache D, Chuin CTH et al (2019) Extraction of cellulose nanofibers and their eco-friendly polymer composites BT-sustainable polymer composites and nanocomposites. In: Thomas S, Kumar Mishra R, Asiri AM (eds) Inamuddin. Springer, Cham, pp 653-691

Herbst A, Janiak C (2016) Selective glucose conversion to 5-hydroxymethylfurfural (5-HMF) instead of levulinic acid with MIL-101Cr MOF-derivatives. New J Chem 40:7958-7967. https://doi.org/10.1039/c6nj01399f

Holtman KM, Offeman RD, Franqui-Villanueva D et al (2015) Countercurrent extraction of soluble sugars from almond hulls and assessment of the bioenergy potential. J Agric Food Chem 63:2490-2498. https://doi.org/10.1021/ jf5048332
Hospodarova V, Singovszka E, Stevulova N (2018) Characterization of cellulosic fibers by FTIR spectroscopy for their further implementation to building materials. Am J Anal Chem 09:303-310. https://doi.org/10.4236/ajac.2018. 96023

Hu F, Jung S, Ragauskas A (2012) Pseudo-lignin formation and its impact on enzymatic hydrolysis. Bioresour Technol 117:7-12. https://doi.org/10.1016/j.biortech.2012.04.037

Hu L, Luo Y, Cai B et al (2014) The degradation of the lignin in Phyllostachys heterocycla cv. pubescens in an ethanol solvothermal system. Green Chem 16:3107-3116. https:// doi.org/10.1039/c3gc42489h

Huang Y, Sun S, Huang C et al (2017) Stimulation and inhibition of enzymatic hydrolysis by organosolv lignins as determined by zeta potential and hydrophobicity. Biotechnol Biofuels 10:1-11. https://doi.org/10.1186/ s13068-017-0853-6

Ilyas RA, Sapuan SM, Ibrahim R et al (2019) Effect of sugar palm nanofibrillated cellulose concentrations on morphological, mechanical andphysical properties of biodegradable films based on agro-waste sugar palm (Arenga pinnata (Wurmb.) Merr) starch. J Mater Res Technol 8:4819-4830. https://doi.org/10.1016/j.jmrt.2019.08.028

Jang JH, Hayashi N, Han SY et al (2020) Changes in the dimensions of lignocellulose nanofibrils with different lignin contents by enzymatic hydrolysis. Polymers (basel). https://doi.org/10.3390/POLYM12102201

Kabakcı SB, Hacıbektaşoğlu Ş (2017) Catalytic pyrolysis of biomass. In: Samer M (ed) Pyrolysis. InTech, London, p 13

Kabir SMF, Sikdar PP, Haque B et al (2018) Cellulose-based hydrogel materials: chemistry, properties and their prospective applications. Prog Biomater 7:153-174. https://doi.org/10.1007/s40204-018-0095-0

Kafle K, Greeson K, Lee C, Kim SH (2014) Cellulose polymorphs and physical properties of cotton fabrics processed with commercial textile mills for mercerization and liquid ammonia treatments. Text Res J 84:1692-1699. https://doi. org/10.1177/0040517514527379

Kargarzadeh H, Ioelovich M, Ahmad I et al (2017) Methods for extraction of nanocellulose from various sources. Handb Nanocellul Cellul Nanocompos. https://doi.org/10.1002/ 9783527689972.ch1

Kobayashi T, Kuramochi H, Maeda K, Xu K (2017) A simple method for the detection of long-chain fatty acids in an anaerobic digestate using a quartz crystal sensor. Energies 10:1-14. https://doi.org/10.3390/en10010019

Kono H, Numata Y (2006) Structural investigation of cellulose I $\alpha$ and I $\beta$ by 2 D RFDR NMR spectroscopy: determination of sequence of magnetically inequivalent D-glucose units along cellulose chain. Cellulose 13:317-326. https://doi. org/10.1007/s10570-005-9025-0

Koschella A, Hartlieb M, Heinze T (2011) A "click-chemistry" approach to cellulose-based hydrogels. Carbohydr Polym 86:154-161. https://doi.org/10.1016/j.carbpol.2011.04. 031

Kumar A, Negi YS, Choudhary V, Bhardwaj NK (2014) Characterization of cellulose nanocrystals produced by acid-hydrolysis from sugarcane bagasse as agro-waste. J Mater Phys Chem 2:1-8. https://doi.org/10.12691/jmpc2-1-1 
Ladesov AV, Belesov AV, Kuznetsova MV et al (2018) Fractionation of wood with binary solvent 1-butyl-3methylimidazolium acetate + dimethyl sulfoxide. Russ J Appl Chem 91:663-670. https://doi.org/10.1134/ S1070427218040201

Lewandowska-Łańcucka J, Karewicz A, Wolski K, Zapotoczny S (2018) Surface functionalization of nanocellulose-based hydrogels. In: Mondal MIH (ed) Cellulose-based superabsorbent hydrogels. Springer, Berlin, pp 1-29

Liu Y, Sun Y, Ding G et al (2015) Synthesis, characterization, and application of microbe-triggered controlled-release kasugamycin-pectin conjugate. J Agric Food Chem 63:4263-4268. https://doi.org/10.1021/jf5055062

Liu Q, Lu Y, Aguedo M et al (2017) Isolation of high-purity cellulose nanofibers from wheat straw through the combined environmentally friendly methods of steam explosion, microwave-assisted hydrolysis, and microfluidization. ACS Sustain Chem Eng 5:6183-6191. https://doi.org/10.1021/acssuschemeng.7b01108

Lu H, Lv C, Zhang M et al (2017) Optimization of hydrothermal pretreatment for co-utilization C-5 and C-6 sugars of cassava alcohol residue. Energy Convers Manag 132:251-260. https://doi.org/10.1016/j.enconman.2016. 11.041

Luque de Castro MD, García Ayuso LE (2000) Environmental applicationslsoxhlet extraction. In: Wilson IDBT-E of SS (ed). Academic Press, Oxford, pp 2701-2709

Lyu GJ, Bin WuS, Lou R (2010) Kinetic study of the thermal decomposition of hemicellulose isolated from corn stalk. BioResources 5:1281-1291. https://doi.org/10.15376/ biores.5.2.1281-1291

Mariotti F, Tomé D, Mirand PP (2008) Converting nitrogen into protein-beyond 6.25 and Jones' factors. Crit Rev Food Sci Nutr 48:177-184. https://doi.org/10.1080/ 10408390701279749

Matharu AS, Houghton JA, Lucas-Torres C, Moreno A (2016b) Acid-free microwave-assisted hydrothermal extraction of pectin and porous cellulose from mango peel waste-towards a zero waste mango biorefinery. Green Chem 18:5280-5287. https://doi.org/10.1039/c6gc01178k

Matharu AS, de Melo EM, Houghton JA (2016a) Opportunity for high value-added chemicals from food supply chain wastes. Bioresour Technol 215:123-130. https://doi.org/ 10.1016/j.biortech.2016.03.039

Matharu AS, de Melo EM, Remón J et al (2018) Processing of citrus nanostructured cellulose: a rigorous design-of-experiment study of the hydrothermal microwave-assisted selective scissoring process. Chemsuschem 11:1344-1353. https://doi.org/10.1002/cssc.201702456

Melo E (2018) Microfibrillated cellulose and high-value chemicals from orange peel residues. University of York, York

Mishra RK, Sabu A, Tiwari SK (2018) Materials chemistry and the futurist eco-friendly applications of nanocellulose: status and prospect. J Saudi Chem Soc 22:949-978. https:// doi.org/10.1016/j.jscs.2018.02.005

Montagnac JA, Davis CR, Tanumihardjo SA (2009) Nutritional value of cassava for use as a staple food and recent advances for improvement. Compr Rev Food Sci Food Saf 8:181-194. https://doi.org/10.1111/j.1541-4337.2009. 00077.x
Nanssou PAK, Jiokap Nono YJ, Kapseu C (2016) Pretreatment of cassava stems and peelings by thermohydrolysis to enhance hydrolysis yield of cellulose in bioethanol production process. Renew Energy 97:252-265. https://doi. org/10.1016/j.renene.2016.05.050

Nasir M, Hashim R, Sulaiman O, Asim M (2017) Nanocellulose. In: Jawaid M, Boufi S, Abdul Khalil HPS (eds) CelluloseReinforced nanofibre composites. Elsevier, Amsterdam, pp 261-276

Novo LP, Bras J, García A et al (2015) Subcritical water: a method for green production of cellulose nanocrystals. ACS Sustain Chem Eng 3:2839-2846. https://doi.org/10. 1021/acssuschemeng.5b00762

Obadina AO, Oyewole OB, Sanni LO, Abiola SS (2006) Fungal enrichment of cassava peels proteins. African J Biotechnol 5:302-304. https://doi.org/10.5897/AJB05.360

Oliaei E, Lindén PA, Wu Q et al (2020) Microfibrillated lignocellulose (MFLC) and nanopaper films from unbleached kraft softwood pulp. Cellulose 27:2325-2341. https://doi. org/10.1007/s10570-019-02934-8

Oliaei E, Berthold F, Berglund LA (2021) Eco-friendly highstrength composites based on hot-pressed lignocellulose micro fibrils or fibers. ACS Sustain Chem Eng. https://doi. org/10.1021/acssuschemeng.0c08498

Pandey A, Soccol CR, Nigam P et al (2000) Biotechnological potential of agro-industrial residues. II: cassava bagasse. Bioresour Technol 74:81-87. https://doi.org/10.1016/ S0960-8524(99)00143-1

Park S, Baker JO, Himmel ME et al (2010) Cellulose crystallinity index: measurement techniques and their impact on interpreting cellulase performance. Biotechnol Biofuels 3:1-10. https://doi.org/10.1186/1754-6834-3-10

Paschoal GB, Muller CMO, Carvalho GM et al (2015) Isolation and characterization of nanofibrillated cellulose from oat hulls. Quim Nova 38:902-909. https://doi.org/10.5935/ 0100-4042.20150029

Pelissari FM, Sobral PJDA, Menegalli FC (2014) Isolation and characterization of cellulose nanofibers from banana peels. Cellulose 21:417-432. https://doi.org/10.1007/s10570013-0138-6

Poletto M, Zattera AJ, Forte MMC, Santana RMC (2012) Thermal decomposition of wood: influence of wood components and cellulose crystallite size. Bioresour Technol 109:148-153. https://doi.org/10.1016/j.biortech.2011.11. 122

Poletto M, Pistor V, Ademir J (2013) Structural characteristics and thermal properties of native cellulose. In: Van De Ven TG (ed) Cellulose-fundamental aspects. InTech, London, p 64

Poletto M, Ornaghi Júnior HL, Zattera AJ (2014) Native cellulose: structure, characterization and thermal properties. Materials (basel) 7:6105-6119. https://doi.org/10.3390/ ma7096105

Pooja NS, Padmaja G (2015) Enhancing the enzymatic saccharification of agricultural and processing residues of cassava through pretreatment techniques. Waste Biomass Valoriz 6:303-315. https://doi.org/10.1007/s12649-0159345-8

$\mathrm{Pu}$ Y, Hu F, Huang F et al (2013) Assessing the molecular structure basis for biomass recalcitrance during dilute acid 
and hydrothermal pretreatments. Biotechnol Biofuels 6:1. https://doi.org/10.1186/1754-6834-6-15

Ralph J, Landucci L (2010) NMR of Lignins. In: Heitner C, Dimmel D, Schmidt J (eds) Lignin and Lignans advances in chemistry. CRC Press, Boca Raton, pp 137-243

Ratnayake WS, Jackson DS (2003) STARCHISources and processing. In: Second E (ed) Caballero BBT-E of FS and N. Academic Press, Oxford, pp 5567-5572

Remón J, Matharu AS, Clark JH (2018) Simultaneous production of lignin and polysaccharide rich aqueous solutions by microwave-assisted hydrothermal treatment of rapeseed meal. Energy Convers Manag 165:634-648. https://doi. org/10.1016/j.enconman.2018.03.091

Remón J, Latorre-Viu J, Matharu AS et al (2020) Analysis and optimisation of a novel 'almond-refinery' concept: simultaneous production of biofuels and value-added chemicals by hydrothermal treatment of almond hulls. Sci Total Environ. https://doi.org/10.1016/j.scitotenv.2020.142671

Ronzon T, Lusser M, Klinkenberg M et al (2017) Bioeconomy report 2016. Brussels

Sabbah M, Esposito M (2016) Insight into zeta potential measurements in biopolymer film preparation. J Biotechnol Biomater 6:2-4. https://doi.org/10.4172/2155-952x. $1000 \mathrm{e} 126$

Salas C, Nypelö T, Rodriguez-Abreu C et al (2014) Nanocellulose properties and applications in colloids and interfaces. Curr Opin Colloid Interface Sci 19:383-396. https:// doi.org/10.1016/j.cocis.2014.10.003

Sannigrahi P, Kim DH, Jung S, Ragauskas A (2011) Pseudolignin and pretreatment chemistry. Energy Environ Sci 4:1306-1310. https://doi.org/10.1039/c0ee00378f

Shanks RA, Pardo IRM (2018) Cellulose solubility, gelation, and absorbency compared with designed synthetic polymers. In: Cellulose-based superabsorbent hydrogels. pp 1-26

Shinde SD, Meng X, Kumar R, Ragauskas AJ (2018) Recent advances in understanding the pseudo-lignin formation in a lignocellulosic biorefinery. Green Chem 20:2192-2205. https://doi.org/10.1039/c8gc00353j

Soares R, Carneiro MC, Monteiroa MIC et al (2009) Simultaneous speciation of chromium by spectrophotometry and multicomponent analysis. Chem Spec Bioavailab 21:153-160. https://doi.org/10.3184/095422909X466095

Soares PAG, Bourbon AI, Vicente AA et al (2014) Development and characterization of hydrogels based on natural polysaccharides: policaju and chitosan. Mater Sci Eng C 42:219-226. https://doi.org/10.1016/j.msec.2014.05.009

Soltani Dashtbozorg S, Invally K, Sancheti A, Ju L-K (2019) Antimicrobial applications of rhamnolipids in agriculture and wound healing. Microb Biosurfactants Environ Ind Appl. https://doi.org/10.1201/b21950-4

Sonobe T (2011) Microwave material processing for green technology. In: 2011 IEEE conference on clean energy and technology CET 2011. pp 297-299. https://doi.org/10. 1109/CET.2011.6041500

Souto LRF, Caliari M, Soares junior MS et al (2016) Utilization of residue from cassava starch processing for production of fermentable sugar by enzymatic hydrolysis. Food Sci Technol 37:19-24.https://doi.org/10.1590/1678-457x.0023

Sweygers N, Alewaters N, Dewil R, Appels L (2018) Microwave effects in the dilute acid hydrolysis of cellulose to 5-hydroxymethylfurfural. Sci Rep 8:1-11. https://doi.org/ 10.1038/s41598-018-26107-y

Syafri E, Sudirman M et al (2019) Effect of sonication time on the thermal stability, moisture absorption, and biodegradation of water hyacinth (Eichhornia crassipes) nanocellulose-filled bengkuang (Pachyrhizus erosus) starch biocomposites. J Mater Res Technol 8:6223-6231. https:// doi.org/10.1016/j.jmrt.2019.10.016

Tazaki K, Fukuyama A, Tazaki F et al (2017) Electron microscopy observation of biomineralization within wood tissues of kurogaki. Minerals 7:123. https://doi.org/10.3390/ $\min 7070123$

Thakur N, Arya V (2014) Preliminary phytochemical analysis of the extracts of psidium leaves. Middle East J Sci Res 19:1421-1424. https://doi.org/10.5829/idosi.mejsr.2014. 19.11.11415

Thakur VK, Thakur MK (2016) Handbook of sustainable polymers. Jenny Stanford Publishing, Dubai

Tholstrup Sejersen M, Salomonsen T, Ipsen R et al (2007) Zeta potential of pectin-stabilised casein aggregates in acidified milk drinks. Int Dairy J 17:302-307. https://doi.org/10. 1016/j.idairyj.2006.03.003

Ullah F, Othman MBH, Javed F et al (2015) Classification, processing and application of hydrogels: a review. Mater Sci Eng C 57:414-433. https://doi.org/10.1016/j.msec. 2015.07.053

Wang SL, Lee JF (2011) Reaction mechanism of hexavalent chromium with cellulose. Chem Eng J 174:289-295. https://doi.org/10.1016/j.cej.2011.09.031

Xia H, Houghton JA, Clark JH, Matharu AS (2016) Potential utilization of unavoidable food supply chain wastes-valorization of pea vine wastes. ACS Sustain Chem Eng 4:6002-6009. https://doi.org/10.1021/acssuschemeng. $6 \mathrm{~b} 01297$

Yang H, Yan R, Chen H et al (2006) In-depth investigation of biomass pyrolysis based on three major components: hemicellulose, cellulose and lignin. Energy Fuels 20:388-393. https://doi.org/10.1021/ef0580117

Yoon SY, Han SH, Shin SJ (2014) The effect of hemicelluloses and lignin on acid hydrolysis of cellulose. Energy 77:19-24. https://doi.org/10.1016/j.energy.2014.01.104

Yu Y, Wang Y, Ding W et al (2017) Preparation of highlyoxidized starch using hydrogen peroxide and its application as a novel ligand for zirconium tanning of leather. Carbohydr Polym 174:823-829. https://doi.org/10.1016/j. carbpol.2017.06.114

Zhang M, Xie L, Yin Z et al (2016) Biorefinery approach for cassava-based industrial wastes: current status and opportunities. Bioresour Technol 215:50-62. https://doi.org/10. 1016/j.biortech.2016.04.026

Zhao J, Ou S, Ding S et al (2011) Effect of activated charcoal treatment of alkaline hydrolysates from sugarcane bagasse on purification of p-coumaric acid. Chem Eng Res Des 89:2176-2181. https://doi.org/10.1016/j.cherd.2011.02. 010

Publisher's Note Springer Nature remains neutral with regard to jurisdictional claims in published maps and institutional affiliations. 